\title{
Epidemiology of Needlesticks and Sharps Injuries among Healthcare Workers and Organizational Safety Climate
}

By

\author{
Alghalban YA ${ }^{1}$, Badr SA ${ }^{1}$, Salem EA ${ }^{1}$, Kasemy ZA ${ }^{1}$, Khooder SA ${ }^{2}$ \\ and El-Bahnasy $\mathbf{R E}^{1}$ \\ ${ }^{1}$ Department of Public Health and Community Medicine, ${ }^{2}$ Department of Clinical \\ Pathology Faculty of Medicine, Menoufia University, Egypt.
}

Corresponding author: Alghalban YA: yousra.alghalban@med.menofia.edu.eg

\begin{abstract}
Introduction: Healthcare workers (HCWs) are exposed to different health hazards as a part of occupational risk including needlestick and sharps injuries (NS\&SIs). Organizational safety climate is considered an important factor in prevention of those injuries Aim of work: to assess the prevalence and risk factors of needle sticks and sharps injuries among HCWs in an Egyptian Governorate hospitals (Menoufia Governorate) and evaluate the organizational safety climate. Materials and methods: An analytical cross sectional study was conducted during the period from May 2018 to May 2019, on 350 HCWs from tertiary and secondary care hospitals in Menoufia Governorate. HCWs were subjected to a predesigned questionnaire about occurrence of NS\&SIs and suspected risk factors, and organizational safety climate scale questionnaire. Results: Prevalence of needlesticks and sharps injury in the last year was $64 \%$; of which more than $65 \%$ had $\geq 2$ injuries. Risk factors of NS\&SIs included being younger age, male sex, working at surgical departments, less work experience, having night shifts, longer working hours/week, using of needles and sharps daily, wearing personal protective equipment and needle recapping. Using syringes daily, surgical specialty, wearing personal protective equipment (PPE) and recapping needles were independent predictors for occurrence of NS\&SIs ( $\mathrm{OR}=7.03,6.27,2.67$ and 2.31; respectively). The best factors attributing to organizational safety climate were the readily accessible sharps containers $81.1 \%$ and open communication between staff nurses and supervisors 78.9\%. Conclusion: The risk of NS\&SIs is still high among HCWs that underlines the emphasis on enhancing the organizational safety climate to decrease the risk of job-related injuries with all its consequences.
\end{abstract}

Keywords: Needle sticks and sharps injuries, Organizational safety climate, Healthcare workers, Likert scale and Hepatitis $\mathrm{C}$ virus 


\section{Introduction}

Healthcare workers are exposed to different health hazards as a part of occupational risk including exposure to blood or other body fluids. Exposure to blood may be through splashes or through contaminated needlesticks or sharp devices (Prüss Üstün et al., 2005). Needlesticks and sharps injuries (NS\&SIs) resulting from sharp and cutting tools cause the risk of transmitting more than 20 types of blood borne pathogens such as hepatitis $\mathrm{B}, \mathrm{C}$ and human immunodeficiency virus (HIV)(Ehsani et al., 2013). The most important factors involved in NSIs events are the knowledge level of blood-borne diseases and standard precautions and adherence to perform those precautions (Mohammadi et al., 2011). Other factors include improper use of protective equipment such as failure to use proper-sized gloves, concerns due to the high workload, long working hours, job stress, fatigue, lack of working personnel, little experience, inadequate training in relation to sharp tools (Gholami et al., 2013). NS\&SIs mostly occur in operating rooms, emergency rooms and ICUs (Smith et al., 2006). Most situations occur at injection, sampling, recapping and while transmitting blood and body fluids from a syringe to the sampling container (Adib-Hajbaghery and Lotfi, 2013). Organizational climate is a fundamental construct in work and organizational settings, as it provides an appropriate context for studying organizational behavior, allowing the exploration of individual and group behaviors. Organizational climate (sometimes known as corporate climate) is the process of quantifying the "culture" of an organization. It is a set of properties of the work environment, perceived directly or indirectly by the employees, that is assumed to be a major force in influencing employee behavior (Diab et al., 2014). As there is scarce research in this field in Menoufia governorates' hospitals at different healthcare levels and also an update assessment is required, this work was conducted.

\section{Aim of work}

To assess the prevalence and risk factors of needle sticks and sharps injuries among HCWs in Menoufia Governorate hospitals and subsequent evaluation of the organizational safety climate.

\section{Materials and methods}

Study design: It is an analytical cross-sectional study 
Place and duration of the study: The study was carried out in one of Egyptian Governorate hospitals (Menoufia Governorate) during the period from May, 2018 to May, 2019. HCWs (doctors, nurses and laboratory technicians) from the selected hospitals had been chosen. The inclusion criterion was to be a current working doctor, nurse or a laboratory technician in the included hospitals for at least one year. Exclusion criteria included refusal to participate.

The chosen governorate has two main tertiary care hospitals (University and Teaching hospitals) and nine secondary care hospitals. The University hospital has bed capacity of 1100 and total workforce consisted of 1518 doctors, 1717 nurses, and 104 laboratory technicians. The teaching hospital has bed capacity of 594 and total workforce consisted of 667 doctors, 551 nurses and 14 laboratory technicians. Out of the nine secondary care hospitals, one central hospital had been chosen. It has bed capacity of 168 and total workforce of 375 doctors, 355 nurses, and 20 laboratory technicians.

\section{Study sample:}

Sample size: It was calculated by using Epi Info (2000) program depending on previous study of Zawilla and Ahmed, (2013) which stated that, at Cairo University Hospitals the rate of HCWs who are experiencing NS\&SIs in the previous year was $(40 \%)$, so at $95 \%$ confidence intervals of and $80 \%$ power of the study, out of the total number of HCWs in the selected hospitals 5438, sample size was calculated to be 384 . Response rate was $90 \%$, so the final sample size was 350 participants. Number of participants of each job category and each hospital was then calculated by propionate allocation method according to their percentage of total number of related HCWs and to the calculated sample size and then participants were chosen by active participation after announcement about the research was distributed among selected hospitals. Most of the participants were from tertiary hospitals (university and teaching hospitals) but only few from a secondary hospital (a central hospital as secondary level care hospital).

\section{Study methods:}

All participants were subjected to:

\section{Predesigned self- administered} questionnaire which included

a- Socio-demographic data, e.g. age, sex, residence, marital status and specialty. 
b- Risk factors for the injury e.g. years of work, working hours per week, night shift, days off after night shifts, number of patients dealt with daily, using of personal protective equipment ( PPE), committing to standard precautions (e.g. wearing PPE, recapping of needles and disposal of sharps in sharp container) and patients' infection status and prior investigations etc.,

c- Relevant bloodborne infections and immunization status: Hepatitis B vaccination, number of doses and time of last dose.

2. Laboratory

Investigation:

Hepatitis $\mathbf{C}$ antibodies Participants who had needle sticks and sharps injuries in the last 12 months were subjected to lab investigations which included detection of Hepatitis $\mathrm{C}$ antibodies by using the enzyme-linked immunosorbent assay technique (ELISA) (BioRad_PR4100 test system with enhanced SAVe, Ortho-clinical Diagnosis, 50-100 Holmers Farm Way, Buckinghamshire, United Kingdom).

3. Evaluation of the organizational safety climate in Menoufia Governorate hospitals using Organizational Safety Climate Scale tool formed and validated by (Gershon et al, 2007) which consists of 20 questions to be selfadministrated by the participants with a likert scale of the five categories of 'Strongly Disagree', 'Disagree', 'No Opinion', 'Agree' or 'Strongly Agree' which were modified by (Diab et al., 2014) to three categories: Agree, No opinion and Disagree. This scale included data about senior management support for safety programs, absence of workplace barriers to safe work practices, cleanliness and orderliness of the work site ....., etc.

Pilot study was carried out on 50 HCWs, excluded from final analysis, to test the methodology applied, tools and the feasibility of the study, to evaluate the adequacy of the questionnaire sheet and to reveal any modifications that might be needed according to the results of the pilot study, to detect problems which might be encountered during the execution of the study and to estimate time needed to obtain the required information.

\section{Consent}

A formal consent was taken from recruited participants before being enrolled and after explanation of the aim, benefits, harms and work of the study. 


\section{Ethical approval}

Medical Ethics Committee at Menoufia Faculty of Medicine approved the study protocol before starting.

\section{Data management}

Data were collected, tabulated, statistically analyzed using an IBM personal computer with IBM Statistical Package of Social Science (SPSS) version 22 (SPSS Inc., Chicago, Illinois, USA). Quantitative data normality was tested using ShapiroWilk and Kolmogorov-Smirnov tests.
Quantitative data were converted into qualitative binary data using the median of the total. Chi- squared test $(\chi 2)$ was used to study association between two qualitative variables, while Fisher's exact test for $2 \times 2$ tables when expected cell count of more than $25 \%$ of cases was less than 5. Logistic regression is used to explain the relationship between one dependent binary variable and one or more nominal, ordinal, interval or ratiolevel independent variables. P-value of $<0.05$ was considered statistically significant. 


\section{Results}

\begin{tabular}{|c|c|c|}
\hline Items & $(\mathrm{No}=350)$ & $\%$ \\
\hline \multicolumn{3}{|l|}{ Prevalence of NS\&SIs } \\
\hline Positive & 224 & 64.0 \\
\hline Negative & 136 & 36.0 \\
\hline \multicolumn{3}{|l|}{ Number of needle sticks and sharps injury } \\
\hline$<2$ injuries & 78 & 34.8 \\
\hline$\geq 2$ injuries & 146 & 65.2 \\
\hline \multicolumn{3}{|l|}{ Type of sharps } \\
\hline Syringe & 74 & 33 \\
\hline IV line & 26 & 11.6 \\
\hline Lancet & 13 & 5.8 \\
\hline Surgical needle & 49 & 21.9 \\
\hline Scalpel & 6 & 2.7 \\
\hline Multiple source & 56 & 25 \\
\hline \multicolumn{3}{|l|}{ Time of injury } \\
\hline Before use & 15 & 6.6 \\
\hline During use & 70 & 31.3 \\
\hline After use (recapping and disposal ) & 139 & 62.1 \\
\hline \multicolumn{3}{|l|}{ The cause of injury from your perspective } \\
\hline Negligence & 47 & 21 \\
\hline Other person's fault & 27 & 12.1 \\
\hline Workload & 110 & 49.1 \\
\hline Non available $\mathrm{PPE}^{\#}$ & 6 & 2.7 \\
\hline Not enough safety boxes & 3 & 1.3 \\
\hline Multiple causes & 31 & 13.8 \\
\hline Prevalence of $\mathrm{HCV}$ & 9 & 4.0 \\
\hline Positive & 215 & 96 \\
\hline
\end{tabular}

"PPE: Personal protective equipment

Table 1 showed that the prevalence of NS\&SIs was 64\%; of which more than 65\% had two or more injuries in the last year. Among the participants who experienced NS\&SIs in the last year, the commonest type of sharps was syringes followed by multiple sources (33\% and 25\%; respectively). Most of the injuries occurred after or during use $(93.4 \%)$ and only a few percent occurred before use. Workload was incriminated as the cause of the injury by about $50 \%$ of the participants. Four percent of the studied HCWs who experienced NS\&SIs had HCV. 
Table (2): Distribution of personal and work related factors regarding needlestick and sharps injuries (NS\&SIs) last year among healthcare workers.

\begin{tabular}{|c|c|c|c|c|c|c|c|c|}
\hline \multicolumn{9}{|l|}{ Age (Years) } \\
\hline$<29$ & 120 & 74.1 & 42 & 25.9 & 162 & 46.3 & & 1.0 \\
\hline$\geq 29$ & 104 & 55.3 & 84 & 44.7 & 188 & 53.7 & 12.3 & $<\mathbf{0 . 0 0 1}^{* *} 2.31(1.47-3.68)$ \\
\hline \multicolumn{9}{|l|}{ Gender } \\
\hline Male & 67 & 75.3 & 22 & 24.7 & 89 & 25.4 & & 1.0 \\
\hline Female & 157 & 60.2 & 104 & 39.8 & 261 & 74.6 & 6.6 & $\mathbf{0 . 0 1 0}^{*} \quad 2.02(1.17-3.5)$ \\
\hline \multicolumn{9}{|l|}{ Education } \\
\hline Secondary & 20 & 62.5 & 12 & 37.5 & 32 & 9.1 & 0034 & 1.0 \\
\hline Institute and University & 204 & 64.5 & 114 & 35.8 & 318 & 90.9 & 0.034 & $0.8531 .07(0.51-2.28)$ \\
\hline \multicolumn{9}{|l|}{ Job title } \\
\hline Physicians & 100 & 59.2 & 69 & 40.8 & 169 & 48.3 & & 1.0 \\
\hline Co-workers & 124 & 68.5 & 57 & 31.5 & 181 & 51.7 & 3.3 & $0.069 \quad 0.67(0.43-1.0)$ \\
\hline \multicolumn{9}{|l|}{ Job specialty } \\
\hline Surgical & 107 & 86.3 & 17 & 13.7 & 124 & 35.4 & 414 & $<0.001^{* *}$ \\
\hline Non-surgical & 117 & 51.8 & 109 & 48.2 & 226 & 64.6 & 41.4 & $5.86(3.3-10.4)$ \\
\hline \multicolumn{9}{|l|}{ Experience years } \\
\hline$<5$ years & 106 & 71.1 & 43 & 28.9 & 149 & 42.6 & & 1.0 \\
\hline$\geq 5$ years & 118 & 58.7 & 83 & 41.3 & 201 & 57.4 & 5.7 & $1.73(1.1-2.7)$ \\
\hline \multicolumn{9}{|l|}{ Night shifts } \\
\hline Yes & 168 & 71.5 & 67 & 28.5 & 137 & 39.1 & & 1.0 \\
\hline $\mathrm{NO}$ & 56 & 48.7 & 59 & 51.3 & 213 & 60.9 & 17.4 & $<\mathbf{0 . 0 0 1}^{* *} 2.64(1.66-4.20)$ \\
\hline \multicolumn{9}{|l|}{$\begin{array}{l}\text { Number of night shift/ } \\
\text { week }(N=235)\end{array}$} \\
\hline$<2$ & 54 & 65.9 & 28 & 34.1 & 82 & 34.9 & & 1.0 \\
\hline$\geq 2$ & 114 & 74.5 & 39 & 25.5 & 153 & 65.1 & 1.9 & $0.1610 .66(0.37-1.18)$ \\
\hline \multicolumn{9}{|l|}{$\begin{array}{l}\text { Days off after night shift } \\
\left(\mathrm{No}_{0}=235\right)\end{array}$} \\
\hline Yes & 89 & 71.8 & 35 & 28.2 & 124 & 52.8 & & 1.0 \\
\hline $\mathrm{N} \mathrm{O}$ & 79 & 71.2 & 32 & 28.8 & 111 & 47.2 & 0.01 & $0.9191 .03(0.9-1.82)$ \\
\hline
\end{tabular}




\begin{tabular}{|c|c|c|c|c|c|c|c|c|}
\hline \multicolumn{9}{|l|}{ Working hours/ week } \\
\hline$<42$ & 83 & 50.9 & 80 & 49.1 & 187 & 53.4 & & 1.0 \\
\hline$\geq 42$ & 141 & 75.4 & 46 & 24.6 & 163 & 46.6 & 22.6 & $<\mathbf{0 . 0 0 1}^{* *} 2.95(1.88-4.65)$ \\
\hline \multicolumn{9}{|l|}{ Number of patients / } \\
\hline $\begin{array}{l}\text { day } \\
<20\end{array}$ & 104 & 59.1 & 54 & 40.9 & 174 & 49.7 & & 1.0 \\
\hline$\geq 20$ & 120 & 69 & 72 & 31 & 176 & 50.3 & 3.7 & $0.0540 .87(0.56-1.34)$ \\
\hline \multicolumn{9}{|l|}{ Hepatitis B vaccine } \\
\hline Yes & 151 & 61.4 & 95 & 38.6 & 246 & 63.1 & & 1.0 \\
\hline $\mathrm{NO}$ & 73 & 70.2 & 31 & 29.8 & 104 & 36.9 & 2.5 & $0.117 \quad 0.67(0.41-1.1)$ \\
\hline \multicolumn{9}{|l|}{ Number of doses } \\
\hline$<3$ & 65 & 67 & 32 & 33 & 97 & 39.4 & & 1.0 \\
\hline$\geq 3$ & 86 & 57.7 & 63 & 42.3 & 149 & 60.6 & 2.1 & $0.143 \quad 1.49(0.87-2.54)$ \\
\hline
\end{tabular}


Table (3) Distribution of needlesticks and sharps injuries (NS\&SIs) regarding sharps use among the studied healthcare workers.

\begin{tabular}{|c|c|c|c|c|c|c|c|c|c|}
\hline \multirow{3}{*}{ Items } & \multicolumn{4}{|c|}{ NS\&SIs } & & \multirow{3}{*}{$\begin{array}{c}\text { Test of } \\
\text { sig }\end{array}$} & \multirow{3}{*}{ p-value } & \multirow{3}{*}{$\begin{array}{c}\text { OR } \\
(95 \% \mathrm{CI})\end{array}$} \\
\hline & \multicolumn{2}{|c|}{$\begin{array}{c}+\mathrm{ve} \\
(\mathrm{No}=224)\end{array}$} & \multicolumn{2}{|c|}{$\begin{array}{c}\text {-ve } \\
\left(\mathrm{No}_{0}=126\right)\end{array}$} & \multicolumn{2}{|c|}{ Total } & & & \\
\hline & No & $\%$ & No & $\%$ & No & $\%$ & & & \\
\hline $\begin{array}{l}\text { Use of syringes/ day } \\
\text { Yes } \\
\text { NO }\end{array}$ & $\begin{array}{c}199 \\
25\end{array}$ & $\begin{array}{l}71.8 \\
34.2\end{array}$ & $\begin{array}{l}78 \\
48\end{array}$ & $\begin{array}{l}28.2 \\
65.8\end{array}$ & $\begin{array}{c}277 \\
73\end{array}$ & $\begin{array}{l}79.1 \\
20.9\end{array}$ & $\begin{array}{c}\chi^{2}= \\
35.4\end{array}$ & $<0.001^{* *}$ & $\begin{array}{c}2.46 \\
(1.40-0.34) \\
1\end{array}$ \\
\hline \begin{tabular}{|l} 
Use of surgical \\
needles/ day \\
Yes \\
$\mathrm{NO}$ \\
\end{tabular} & $\begin{array}{l}102 \\
122\end{array}$ & $\begin{array}{l}76.1 \\
56.5\end{array}$ & $\begin{array}{l}32 \\
94\end{array}$ & $\begin{array}{l}23.9 \\
43.5\end{array}$ & $\begin{array}{l}134 \\
216\end{array}$ & $\begin{array}{l}38.3 \\
61.7\end{array}$ & $\begin{array}{l}\chi^{2}= \\
13.8\end{array}$ & $<0.001^{* *}$ & $\begin{array}{c}2.46 \\
(1.52-3.97) \\
1\end{array}$ \\
\hline $\begin{array}{l}\text { Use of scalpels/day } \\
\text { Yes } \\
\text { NO }\end{array}$ & $\begin{array}{c}151 \\
73\end{array}$ & $\begin{array}{l}70.2 \\
54.1\end{array}$ & $\begin{array}{l}64 \\
62\end{array}$ & $\begin{array}{l}29.8 \\
45.9\end{array}$ & $\begin{array}{l}215 \\
135\end{array}$ & $\begin{array}{l}61.4 \\
38.6\end{array}$ & $\chi^{2}=9.4$ & $0.002 *$ & $\begin{array}{c}2.0 \\
(1.28-3.13) \\
1\end{array}$ \\
\hline Behavioral factors $r$ & lated & o shat & s use & & & & & & \\
\hline $\begin{array}{l}\text { Needle recapping } \\
\text { Yes } \\
\text { NO }\end{array}$ & $\begin{array}{c}151 \\
73\end{array}$ & $\begin{array}{l}68.3 \\
56.6\end{array}$ & $\begin{array}{l}70 \\
56\end{array}$ & $\begin{array}{l}31.7 \\
43.4\end{array}$ & $\begin{array}{l}221 \\
129\end{array}$ & $\begin{array}{l}63.1 \\
36.9\end{array}$ & $\chi^{2}=4.9$ & $0.027^{*}$ & $\begin{array}{c}1.65 \\
(1.1-2.59) \\
1\end{array}$ \\
\hline $\begin{array}{l}\text { Immediately } \\
\text { throwing the } \\
\text { sharps in safety box } \\
\text { Yes } \\
\text { NO }\end{array}$ & $\begin{array}{c}220 \\
4\end{array}$ & $\begin{array}{c}63.8 \\
80\end{array}$ & $\begin{array}{c}125 \\
1\end{array}$ & $\begin{array}{c}36.2 \\
20\end{array}$ & $\begin{array}{c}345 \\
5\end{array}$ & $\begin{array}{c}98.6 \\
1.4\end{array}$ & $\begin{array}{l}\text { Fisher's } \\
\text { Exact } \\
=0.56\end{array}$ & 0.658 & $\begin{array}{c}0.44 \\
(0.05-3.9) \\
1\end{array}$ \\
\hline $\begin{array}{l}\text { Wear personal } \\
\text { protective } \\
\text { equipment } \\
\text { Yes } \\
\text { NO }\end{array}$ & $\begin{array}{c}177 \\
47\end{array}$ & $\begin{array}{c}70.2 \\
48\end{array}$ & $\begin{array}{l}75 \\
51\end{array}$ & $\begin{array}{c}29.8 \\
52\end{array}$ & $\begin{array}{c}252 \\
98\end{array}$ & $\begin{array}{l}72 \\
28\end{array}$ & $\begin{array}{l}\chi^{2}= \\
15.2\end{array}$ & $<0.001^{* *}$ & $\begin{array}{c}2.56 \\
(1.59-4.1) \\
1\end{array}$ \\
\hline
\end{tabular}

*: Statistically significant

**: Highly statistically significant

Table 3 showed that based on univariate analysis, risk factors of NS\&SI included using of syringes, surgical needles and scalpels daily, needle recapping and wearing personal protective equipment. 
Table (4): Regression analysis of risk factors of needlestick and sharps injuries.

\begin{tabular}{|l|c|c|c|c|}
\hline \multicolumn{1}{|c|}{ Predictors } & Wald & OR & CI 95\% & p value \\
\hline $\begin{array}{l}\text { Using syringes } \\
\text { daily }\end{array}$ & 26.9 & 7.03 & $3.36-14.67$ & $<\mathbf{0 . 0 0 1}^{* * *}$ \\
\hline $\begin{array}{l}\text { Job specialty } \\
\text { (surgical) }\end{array}$ & 19.9 & 6.27 & $2.80-14.05$ & $<\mathbf{0 . 0 0 1}^{* *}$ \\
\hline Wearing PPE & 10.89 & 2.67 & $1.49-4.80$ & $\mathbf{0 . 0 0 1}^{* *}$ \\
\hline $\begin{array}{l}\text { Recapping } \\
\text { needles }\end{array}$ & 8.26 & 2.31 & $1.31-4.09$ & $\mathbf{0 . 0 0 4}^{* *}$ \\
\hline
\end{tabular}

*: Statistically significant

**: Highly statistically significant

"PPE: Personal protective equipment

Variables included in the binary regression model were: gender, age, marital status, job specialty, experience years, working hours per week, night shift, syringe use, surgical needles use, scalpels use, recapping of needles and wearing PPE. Table 4 showed that using syringes daily, surgical job specialty, wearing PPE and recapping needles are independent predictors for occurrence of needlestick and sharps injuries with odds ratio (7.03, 6.27, 2.67 and 2.31; respectively). 


\section{Figure (1): Organizational safety climate}

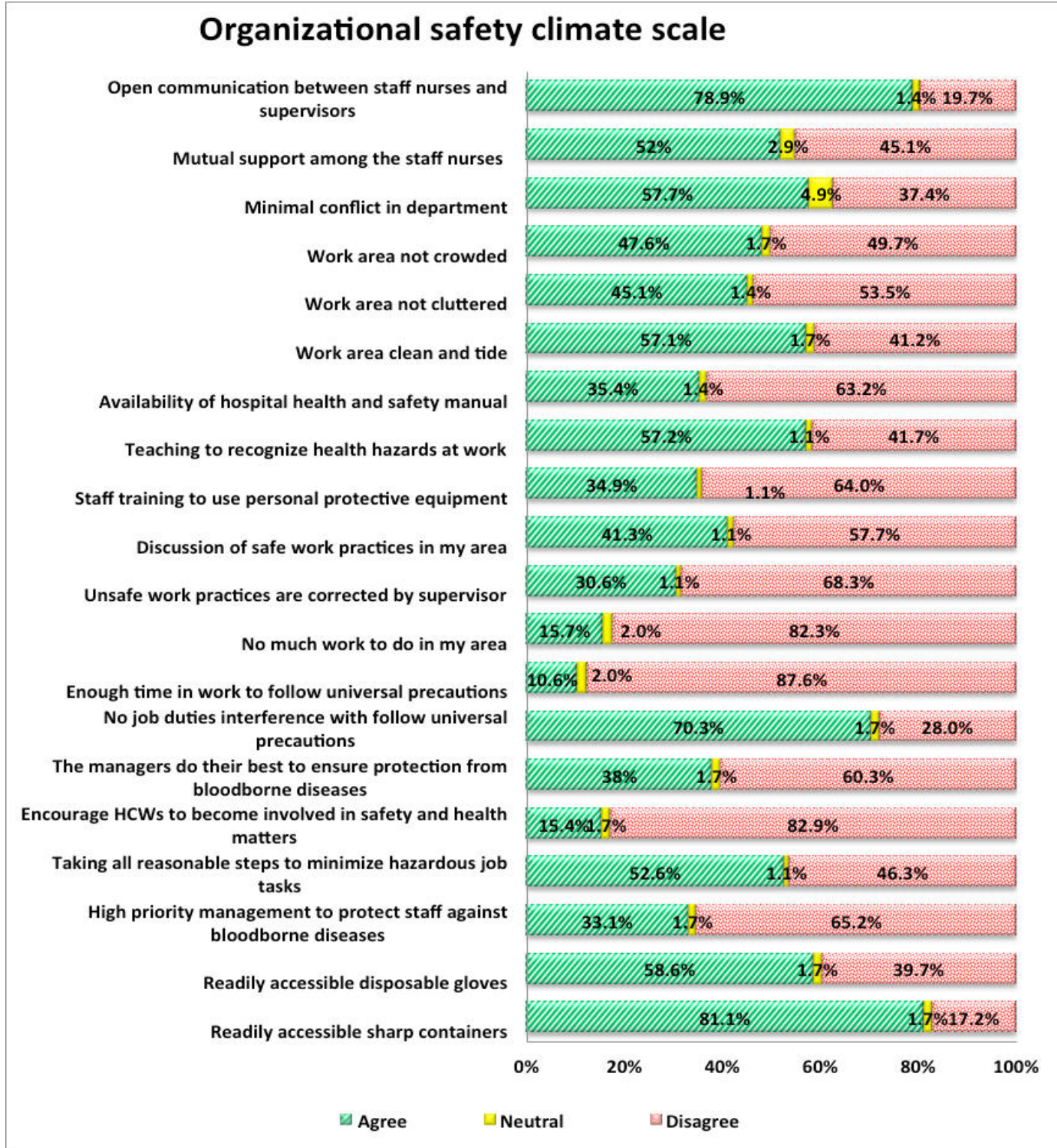

Fig 1 showed that the highest percentage of "Agree" answers were on readily accessible sharps containers $81.1 \%$ and open communication between staff nurses and supervisors $78.9 \%$ and the highest percentage of "Disagree" were on enough time in work to follow universal precautions $87.6 \%$ and encourage HCWs to become involved in safety and health matters $82.9 \%$. 


\section{Discussion}

The occupational health of healthcare workers, representing 12\% of working population, has long been neglected both organizationally and by governments with misconception that the healthcare industry is "clean and without hazard" (Wilburn and Eijkemans, 2004). Needlesticks and sharps injuries and/or blood exposures were associated with the transmission of more than twenty pathogens (CDC, 2008).

The present study revealed that the prevalence of NS\&SIs in the last year was $64 \%$ (Table 1). Comparing this result with previous studies in Egypt; it comes in agreement with a study done by Hanafi et al., 2011 on needlestick injuries among health care workers of Alexandria Hospitals University in which NS\&SIs was experienced by more than two-thirds of HCWs in the last year. The prevalence detected in the current study was higher than what was found by (Zawillaa and Ahmed, 2013) which was $40 \%$ and lower from what was observed by Gabr et al., 2018, as the prevalence of NS\&SIs was $83 \%$ on the last three months.
Among the participants who experienced needlesticks and sharps injury in the last year, more than $65 \%$ had two or more injuries (Table 1), which is comparable to the study of Hanafi et al., 2011, in which more than half of the participants who experienced NS\&SIs had two or more injuries in the previous year. The percentage of participants who had two or more injuries in the current study was lower than what was observed by Gabr et al., 2018, who detected that $85 \%$ of their studied group experienced NS\& SIs had two or more injuries in the last 3 months. The commonest type of sharps incriminated in causing injury was syringes followed by multiple sources with (33\% and 25\%; respectively) (Table 1), which was in accordance with the results reached by Hanafi et al., 2011, where disposable syringes accounted for the highest proportion of injuries and Ahmed, 2014 who stated that the most frequent causative tools was hollow-bore needle (more than three-quarters) and with (Foster, 2010 and Garus-Pakowska1 and Górajski, 2019) where the hollow bore needle was the tool responsible for the greatest number of the NS\&SI. 
Most of the injuries occurred after use of the sharps $(62.1 \%)$ or during use $(31.3 \%)$ and only a few percent $(6.6 \%)$ occurred before use (Table 1), which comes in agreement with the study of Hanafi et al., 2011, where most of the injuries $(80 \%)$ occurred after use (after use and before disposal, recapping and inappropriate or appropriate disposal), and different than results obtained by (Talaat et al., 2003, Lee and Hassim, 2005, Hashmi et al., 2012 and Matlab et al., 2017), where more than twothirds of the injury occurred during use of sharps.

The majority of the exposed participants (78.1\%) applied personal protective equipment when the injury happened. Work load was accused as the cause of the injury by $49.1 \%$, followed by multiple other causes (13.8\%) (Table 1 ). Based on univariate analysis, risk factors of NS\&SIs were being younger age and male, working at surgical departments, having night shifts and longer working hours/week, using of syringes, surgical needles and scalpels, needle recapping and wearing personal protective equipment (Table 2, 3). Participants with age lower than 29 years had higher prevalence of needlestick and sharps injuries; which can be attributed to less experience or longer working hours with higher workload, this comes in agreement with Gholami et al., 2013 who stated that the mean age of injured HCWs was significantly lower than the age of those not injured and Hanafi et al., 2011, who found that the prevalence of NS\&SI were significantly lower with age older than 40 years.

The prevalence of NS\&SIs were significantly higher among males compared to females, which is similar to the study of Oluwatosin et al., 2016, in which male workers were likely to sustain more NS\&SIs than female workers and in disagree with the study of Gabr et al., 2018 in which being a female was recognized as a risk factor to NS\&SIs occurrence. While Hanafi et al., 2011, Gholami et al., 2013 found no difference in the prevalence in relation to gender.

The prevalence of NS\&SIs was higher among HCWs at surgical than non-surgical departments (Table 2), which can be explained by the higher rate of use of sharps among surgical departments, higher workload, more urgent and bloody the field is, this can be supported with several studies; Ilhan et al., 2006 in their study on long working hours increase the risk of sharp 
and needlestick injury among nurses; who found that working in surgical or intensive care units was associated with higher prevalence of NS\&SI. Also it was similar to the study of Alamgir et al., 2008, on needlestick and other potential blood and body fluid exposures among health care workers in British Columbia, Canada; in which sharps incidents occurred primarily in operating rooms. American College of Surgeons, 2016 stated that NS\&SIs rates had been decreasing among non-surgical HCWs, yet they have not declined among health care professionals who work in surgical settings. Ouyang et al., 2017 declared that surgical trainees were significantly more likely to incur injuries than nonsurgical trainees. Alghamdi et al., 2018 demonstrated that more than half of surgical residents were exposed to injuries.

In the present study, we found that NS\&SIs was higher in participants who had night shifts (Table 2), which can be explained by higher workload with higher number of patients specially at night, lack of sleep or disturbed sleep pattern, which was in agreement with the study of Suzuki et al., 2004 who revealed significant associations between experience of medical errors as NS\&SIs in the past 12 months, with night or irregular shift work .Also the results of this work was in accordance with that of (Verma et al., 2018) about night shifts versus day shifts, were they found that participants who had night shifts had less job satisfaction and psychological health problems than day shifts workers.

Prevalence of NS\&SIs was significantly higher with longer working hours per week (Table 2), which is in concordance with Smith et al., 2006 who observed higher rate of NS\&SIs among participants who had longer working hours per week and Kakizaki et al., 2011 who found if they worked $\geq 35$ hours per week.

Using sharps (syringes, surgical needles, scalpels) on daily basis was observed to be a risk factor for occurrence of needlestick and sharps injuries (Table 3 ), which can be attributed to increased duration of exposure to the hazard, and the possibility of decreased awareness to safety precautions with prolonged and accustomed exposure and use.

Personal behavior of participants in relation to sharps use was found to be significantly related to the prevalence as 
it was higher with needle recapping and wearing personal protective equipment, but not with immediate throwing the sharps in safety box (Table 3). This could be explained by having only few number who didn't immediately throw sharps away in sharps container making it hard to attain statistical difference; which is in accordance with other studies as (Prüss-Üstün, 2003, Kermode, 2005 and Ebrahimi, 2007), where recapping of needle was documented as an important factor in occurrence of NS\&SI.

The highest percentage of "Agree" answers were on readily accessible sharps containers $81.1 \%$ and open communication between staff nurses and supervisors 78.9\% (Figure 1). These high results in "Agree" can be attributed to the activity of infection control unit including staff from different departments, who respond fast to any requirements. This was similar to the study of (Diab, 2014) where the highest percentages of organizational safety climate items were readily accessible disposable gloves and open communication between staff nurses and supervisors $(82.7 \%$ and $81.6 \%$; respectively).
The highest percentage of "Disagree" were on enough time in work to follow universal precautions $87.6 \%$ and encourage $\mathrm{HCW}$ s to become involved in safety and health matters $82.9 \%$ (Figure 1). This was in accordance to the study of (Diab, 2014) as the lowest "Agree" items were "Enough time in work to follow universal precautions, and Encouragement of nurses to be involved in safety and health matters with (5.2\% and 9.4\%; respectively).

\section{Conclusion and recommendations:}

The risk of NS\&SIs is still high among HCWs that underline the emphasis on enhancing the organizational safety climate to decrease the risk of job-related injuries with all its consequences.

\section{Conflict of interest}

None declared

\section{Funding}

None

\section{Acknowledgement}

The authors would like to thank the participants who generously agreed to participate in this work for their time to provide valuable information. 


\section{References}

1. Adib-Hajbaghery M and Lotfi MS (2013): Behavior of Healthcare Workers after Injuries from Sharp Instruments. Trauma Mon; 18(2): 75-80.

2. Ahmed AS (2014): Needle Stick and Sharp Injuries among Nurses at Zagazig University Hospitals, Sharkia Governorate, Egypt. Middle East J Appl Sci; 4(4): 120511.

3. Alamgir H, Cvitkovich $\mathrm{Y}$, Astrakianakis G, Yu S and Yassi A(2008): Needlestick and other potential blood and body fluid exposures among health care workers in British Columbia, Canada . Am J Infect Control; 36(1):12-21.

4. Center for Disease Control and Prevention (CDC) (2008): Workbook for Designing, Implementing and Evaluating a Sharps Injury Prevention Program. Available at https://www.cdc.gov/sharpssafety/, last accessed July 2019.

5. Diab GM, Soliman GH and Kasmey ZA (2014): Organizational Safety Climate and Psychosocial Risk Factor: Their relation to Needle-stick and sharps Injuries among Nurses. Zagazig Nursing Journal; 10 (2):101-17.

6. Ebrahimi H and Khosravi A (2007): Needlestick Injuries among Nurses. J Res Health Sci;7(2):56-62
7. Ehsani SR, Mohammad-Nejad E, Hadizadeh MR, Mozaffari J, Ranjbaran S et al., (2013): Epidemiology of Needle Sticks and Sharp Injuries among Nurses in an Iranian Teaching Hospital. Arch Clin Infect Dis; 8(1): 27-30.

8. FitzSimons D, François G, De Carli G, Shouval D, Prüss-Ustün A et al., (2008): Hepatitis $\mathrm{B}$ virus, hepatitis $\mathrm{C}$ virus and other blood-borne infections in healthcare workers: guidelines for prevention and management in industrialised countries. Occup Environ Med; 65(7):446-51.

9. Foster TM (2010): Prevalence of needle stick injuries and other high risk exposures among healthcare workers in Jamaica. West Indian Med J; 59(2): 153-8.

10. Gabr HM, El-Badry AS and Younis FE (2018): Risk factors associated with needlestick injuries among health care workers in Menoufia governorate, Egypt. Int J Occup Environ Med; 9:63-8.

11. Gabriele d'Ettorre (2017): Needle stick and Sharp Injuries among Registered Nurses: A Case-Control Study. Ann Work Expo Health; 61(5), 596-9.

12. Garus-Pakowska1 $\mathrm{A}$ and Górajski $\mathrm{M}$ (2019): Epidemiology of needlestick and sharp injuries among health care workers based on records from 252 hospitals for the period 2010-2014, Poland. BMC Public Health; 19:634-42. 
13. Gershon RR, Stone PW, Zeltser M, Faucett J, MacDavitt K et al., (2007): Organizational climate and nurse health outcomes in the United States: a systematic review. Industrial Health; 45(5): 622-36.

14. Gholami A, Borji A, Lotfabadi P and Asghari A (2013): Risk Factors of Needlestick and Sharps Injuries among Healthcare Workers. Int J Hosp Res; 2(1):31-8.

15. Hanafi MI, Mohamed AM, Kassem MS and Shawki M (2011): Needlestick injuries among health care workers of University of Alexandria hospitals. East Mediterr Health $\mathrm{J} ; 17(1): 26-35$.

16. Hashmi A, Al Reesh SA and Indah L (2012): Prevalence of Needle-stick and Sharps Injuries among Healthcare Workers, Najran, Saudi Arabia: Epidemiology open access; 2(2):117-22.

17. Ilhan MN, Durukan E, Aras E, Turkcuoglu S and Aygun R (2006): Long working hours increase the risk of sharp and Needlestick injury in nurses: the need for new policy implication. J Adv Nurs; 56(5):5638

18. Jayanth ST, Kirupakaran H, Brahmadathan KN, Gnanaraj L and Kang G(2009): needle stick injuries in a tertiary care hospital. Indian J Med Microbiol; 27(1): 44-7.

19. Kakizaki M, Ikeda N, Ali M, Enkhtuya B and Tsolmon M et al., (2011): Needlestick and sharps injuries among health care workers at public tertiary hospitals in an urban community in Mongolia: BMC Res Notes; 4:184-9.

20. Kermode M, Jolley D, Langkham B, Thomas MS and Crofts N (2005): Occupational exposure to blood and risk of blood borne virus infection among health care workers in rural north Indian health care settings. Am J Infect Control; 33(1), 34-41.

21. Lee LK and Hassim IN (2005): Implication of the Prevalence of Needlestick Injuries in a General Hospital in Malaysia and its Risk in Clinical Practice. Environ Health Prev Med; 10(1):33-41.

22. Matlab M, Cowman S, Al-Shagag A and Aboabdo M (2017): Needle Stick Injuries and Compliance among Doctors and Nurses. Bahrain Medical Bulletin; 39(4), 225-8.

23. Mohammadi N, Allami A and MalekMohamadi R (2011): Percutaneous exposure incidents in nurses: Knowledge, practice and exposure to hepatitis $B$ infection. Hepat Mon; 11(3):186-90.

24. National Institute for Occupational Safety and Health (NIOSH) (2012): Fact sheet Home Healthcare workers, How to Prevent Needlestick and Sharps Injuries. NIOSH 2012; DHHS (NIOSH) Publication No. 2012-123. Available at https://www.cdc. gov/niosh/nioshtic-2/20040333.html, last accessed August 2019. 
25. Oluwatosin OA, Oladapo MM and Asuzu MC (2016): Needlestick injuries among healthcare workers in Ondo State, Nigeria. Int J Med Public Health; 6:31-4.

26. Ouyang B, DX Li L, Mount J, Jamal AJ and Berry L et al., (2017): Incidence and characteristics of needlestick injuries among medical trainees at a community teaching hospital: A cross-sectional study. J Occup Health; 59(1): 63-73.

27. Prüss-Üstün A, Rapiti E and Hutin $Y$ (2005): Estimation of the Global Burden of Disease attributable to Contaminated Sharps Injuries among Health-Care Workers. Am J Ind Med; 48:482-90.

28. Rais N and Jamil HM (2013): Prevalence of needle sticks injuries among health care providers. Int J Endorsing Health Sci Res; 1(2): 73-9.

29. Smith DR, Choe MA, Jeong JS, Jeon MY , Chae YR, et al., (2006): Epidemiology of needlestick and sharps injuries among professional Korean nurses. J Prof Nurs; 22(6): 359-66.
30. Suzuki K, Ohida T, Kaneita Y, Yokoyama E, Miyake T, et al., (2004): Mental health status, shift work, and occupational accidents among hospital nurses in Japan. J Occup Health; 46(6):44854.

31. Talaat M, Kandeel A, El-Shoubary W, Bodenschatz C , Khairy I, et al., (2003): Occupational Exposure to Needlestick Injuries and Hepatitis B Vaccination Coverage among Health Care Workers in Egypt. Am J Infect Control; 31(8):469-74.

32. Verma A, Kishore J and Gusain S (2018): A Comparative Study of Shift Work Effects and Injuries among Nurses Working in Rotating Night and Day Shifts in a Tertiary Care Hospital of North India. Iran J Nurs Midwifery Res; 23(1): 51-6.

33. Zawillaa NH and Ahmed D (2013): Sharps injuries among healthcare workers in Cairo University Hospitals. Int J Risk Saf Med; 25: 79-92. 